orderly conduct, good temper, and the pleasure evinced by the twentyeight inhabitants of the Home." ". . . "We would commend Mr. Corbyn's narrative to the study of those who, like Sir $W^{T}$. Denison, enter the lists in a mild fashion against Mr. Darwin and Professor Huxley, in defence of the dignity of the race and its generic difference from the gorilla. If $\mathrm{Mr}$. Corbyn's record is to be trusted, the fact that the most degraded specimens of humanity yet discovered can be taught in a few weeks to show extraordinary memory 'and quick intelligence,' to distinguish the letters of our alphabet and read words of two syllables, will not be overlooked by those who hold the old-fashioned belief that God made man in His own image."

Southampton, 3rd October.

\title{
Mr. Guppy's Article on Trinidad Rocks.
}

Mr dear Sir, - I am very sorry to see by your last number that $\mathrm{Mr}$. Guppy has most unaccountably misapprehended the tenor and purpose of my former letter to you. I was perfectly aware that $\mathrm{Mr}$. Guppy was not the authority for the correlation of the beds in question with the Neocomian of Europe; nor do I for one moment raise any objection to the connection of the two series of rocks. I merely objected to the use of the term " age;" and without dissenting in one particular from Mr. Guppy's statements, took the opportunity of referring to Professor Huxley's views on "homotaxis." Your correspondent himself states that he has held views similar to those in question; and $I$ am, therefore, surprised that he should have troubled himself to enter into an explanation on other matters, which was alike unnecessary and uncalted for.

Iset me assure Mr. Guppy that I concur in all that he has written on this matter, saving the one word "age;" and I am sorry that he should have thought it worth while to correct an error which had no existence but in his own imagination.

Yours truly,

E. R. LANGESTER.

8, Savile Rov, $W$.

\section{PROCEEDINGS OF GEOLOGICAL SOCIETIES.}

Liverpool Geological Societr.- The abstracts of the proceedings of this useful society, for the sessions of $1861-2$ and 1862-3, have just been printed; they commence with the Report of the Excursion to Holywell on the 11th July, 1861 .

The mountain limestone of that neighbourhood contains many species of the ordinary fossils in profusion,-Productus giganteus, $P$. semireticulatus, Lithostrotion basaltiforme, and Syringopora geniculata being the most common. The formation is there divided into the following sub. divisions :- -1 , numerous beds of Chert ; 2 , Shale and Limestone, with concretions of chert; 3, Black Limestone; 4. White Limestone. The position of the chert nodules in No. 2 is similar to that of the flints in the Chalk, but their form is different, being round flat concretions, thick in the centre, and gradually thinning towards the circumference.

Next follows the Report of the Excursion to Coalbrookdale, on July 31 st.

vOL. VI. 